\title{
Gastric Cancer Stem Cells: Current Insights into the Immune Microenvironment and Therapeutic Targets
}

\author{
Lingfeng Fu ${ }^{1,2}$, Luke Bu ${ }^{1,2}$, Tadahito Yasuda ${ }^{1,2}$, Mayu Koiwa ${ }^{1,2}$, Takahiko Akiyama ${ }^{1,2}$, \\ Tomoyuki Uchihara ${ }^{1,2}$, Hideo Baba ${ }^{2, *}$ and Takatsugu Ishimoto ${ }^{1,2, *}$ \\ 1 Gastrointestinal Cancer Biology, International Research Center of Medical Sciences (IRCMS), Kumamoto \\ University, Kumamoto 860-0811, Japan; flf_0228@yahoo.co.jp (L.F.); buluke1221@yahoo.co.jp (L.B.); \\ kumasyuwa@gmail.com (T.Y.); mk.transit.in@gmail.com (M.K.); theaki50220@gmail.com (T.A.); \\ tomoyuki.u.mikawa1@gmail.com (T.U.) \\ 2 Department of Gastroenterological Surgery, Graduate School of Medical Sciences, Kumamoto University, \\ 1-1-1 Honjo, Kumamoto 860-8556, Japan \\ * Correspondence: hdobaba@kumamoto-u.ac.jp (H.B.); taka1516@kumamoto-u.ac.jp (T.I.); \\ Tel.: +81-96-373-5213 (H.B.); +81-96-373-5211 (T.I.); Fax: +81-96-371-4378 (T.I.)
}

Received: 25 November 2019; Accepted: 4 January 2020; Published: 6 January 2020

\begin{abstract}
Gastric cancer (GC) is a leading cause of cancer-related death worldwide. Cancer stem cells (CSCs) are known to be involved in chemotherapy resistance and the development of metastases. Although CSCs harbor self-renewal and tumorigenic abilities, the immune microenvironment surrounding CSCs provides various factors and supports the maintenance of CSC properties. The current review summarizes the accumulating findings regarding the relationship between the immune microenvironment and gastric CSCs (GCSCs), which will support the possibility of developing novel therapeutic strategies for targeting GCSCs.
\end{abstract}

Keywords: gastric cancer; gastric cancer stem cell; immune microenvironment; cancer therapy

\section{Introduction}

Gastric cancer (GC) is fifth in incidence and third in mortality among all cancers worldwide (GLOBOCAN 2018). In epidemiological studies, the incidence of GCs is generally approximately twice as high in men as in women, and there are great differences among different countries [1]. Eastern Asia, Central and Eastern Europe, and South America have higher incidence rates than Northern America and most parts of Africa [1]. These regional differences reflect differences in dietary patterns, food storage, and fresh produce availability, as well as differences in the prevalence of Helicobacter pylori infection [2].

Despite advances in treatment for GC patients, tumor relapse and metastasis lead to poor overall survival. The cancer stem cell (CSC) model has been proposed to explain tumor relapse and resistance [3]. CSCs have been identified in many solid malignancies, including GCs, and targeting the CSC population may be essential to prevent tumor relapse and spread [4]. In addition, specific markers of CSCs have been explored in recent decades. A large number of studies have shown that CSC tends to share cell surface markers with tissue stem cells, and the expression of CSC markers will affect the characteristics of CSC, including tumorigenicity, chemoresistance and invasive abilities [5]. Because of this, it also provides guidance for investigations on CSC markers.

This review provides a better understanding of the role of gastric cancer stem cells (GCSCs) in GC progression and the plasticity mediated by the tumor microenvironment. 


\section{GCSC Markers}

CD44 was the first GCSC marker identified, and it was found by using GC cell lines. The CD44 positive cells have obvious tumorigenic characteristics. It is known that CD44 positive cells do not only form spheroids in vitro, but also form tumors when injected into the gastric wall of immunodeficient mice [6]. In addition, CD44 positive/CD24 positive cells are also found as CSCs in GC tissues. An investigation further showed that the CD44 positive /CD24 positive fraction demonstrated higher tumorigenicity than the CD44 negative/CD24 negative fraction when injected into immunodeficient mice. CD44 positive /CD24 positive cells have been suggested to have the ability of self-renew and to produce differentiated progeny as CSCs, suggesting that the combined expression of CD44 and CD24 can be used as a possible GCSC marker [7]. In addition, the cell-surface markers CD44 and CD54 can be used to isolate CSCs from the peripheral blood of GC patients, and tumors generated by CD44 positive /CD54 positive cell transplantation into the immunodeficient mice are similar to the original tumors in patients. CD44 positive/CD54 positive cells are identified as markers of GCSCs because these cells can differentiate into gastric epithelial cells in vitro and these kind of cells have the ability to undergo self-renewal in vivo. [8]. Similarly, the combination of epithelial cell adhesion molecule (EpCAM) and CD44 have also been found as putative GCSC markers. The EpCAM positive/CD44 positive fraction in human GC tissues has the tumorigenic ability after injection into immunodeficient mice, maintains histological differentiation, and reproduce the phenotypical heterogeneities of the primary tumors. In addition, this fraction has a stronger resistance to anticancer drugs than the other fractions [9].

Aldehyde dehydrogenase 1 (ALDH1) has been used as a marker for cancer-initiating cells (CICs), and ALDH1 positive cells have been detected in diffuse GC in recent years; this is because ALDH1 positive cells show strong tumorigenicity, self-renewal and the ability to generate tumor hierarchy and heterogeneity in vivo. ALDH1 positive cells are also one of the markers of GCSCs. Further studies have shown that ALDH1 positive GCSCs are involved in regenerating islet-derived family member 4 (REG4), which is a factor related to tumorigenicity, cell growth, survival and apoptosis. The REG4 expression is down-regulated by transforming growth factor- $\beta$ (TGF- $\beta$ ) in ALDH1 positive GCSCs, which correlates with reductions in the GCSC population and tumorigenicity [10,11].

Various studies have investigated whether GCSCs are enriched through spheroid formation in a human GC cell line in defined serum-free medium. Spheroid body-forming cells are recognized to have GCSC properties, including self-renewal, continuous proliferation, drug resistance, high tumorigenicity, and over-expression of CD44 and other stem cell related genes and proteins [12]. Another group demonstrated that CD90 might be a potential GCSC marker. CD90 positive GC cells showed a greater tumorigenic ability in vivo than CD90 negative GC cells and could reestablish the hierarchical tumors from a single tumor cell, demonstrating their self-renewal properties. In addition, ERBB2 was highly expressed in about $25 \%$ of gastric tumor models, which correlated with the elevated level of CD90 expression in these tumors. Treatment with trastuzumab could reduce the CD90 positive GCSC frequency in the whole tumor mass and suppress tumor growth when combined with conventional chemotherapeutic agents [13].

The CD71 negative population is enriched in MKN1 cells after treatment with 5-fluorouracil and accumulates during the G0/G1 cell cycle phase. The CD71 negative population shows high resistance to conventional chemotherapeutic agents, which indicates their stem-like cell properties. Additionally, serial transplantation assays have demonstrated that the CD71 negative population has higher tumorigenicity than the CD71 positive population [14]. It has been proved that CD133 is a candidate molecule for GCSC markers. The expression of three candidates of CSC markers, ATP-binding cassette subfamily B member 1, ATP-binding cassette subfamily G member 2, and CD133, were investigated in 90 human GC tissue samples. The expression levels of these markers in GC varied with the histological differentiation status; poorly differentiated GC expressed these markers at a high level [15]. Moreover, the expression of CD133 in GC cells can be divided into two types: luminal expression in the gland and cytoplasmic expression. Notably, the cytoplasmic CD133 expression was useful as an independent prognostic factor in GC patients [16]. 
A few new markers have been identified in recent years. C-X-C chemokine receptor type 4 (CXCR4) is a CSC marker, and CXCR positive GCSCs can promote tumorigenicity in mice and chemoresistance due to their dormancy [17]. The adult stem cell marker leucine-rich repeat-containing, G protein-coupled receptor 5 (Lgr5) has been shown to be involved in the properties of CSCs in cancer cell populations. Moreover, Lgr5 is more highly expressed in a significant fraction of gastrointestinal tumors than in normal tissue $[18,19]$. Given this evidence, Lgr5 may be a possible GCSC marker. We summarize these markers in Table 1. Accumulating evidence suggests that GCSCs may exist at the base of GCs; thus, the understanding of GCSC markers will help us to target GCSC signaling pathways to regulate the self-renewal and differentiation processes of GCSCs.

Table 1. Gastric cancer stem cell markers.

\begin{tabular}{ccc}
\hline Marker & Significance & References \\
\hline CD44 & Tumorigenicity, spheroid formation, chemoresistance & {$[6]$} \\
CD24/CD44 & Tumorigenicity & {$[7]$} \\
CD54/CD44 & Tumorigenicity, hierarchical organization & {$[8]$} \\
EpCAM/CD44 & Tumorigenicity, phenotypical heterogeneity, & {$[9]$} \\
chemoresistance & {$[10,11]$} \\
CD90 & Tumorigenicity, phenotypical heterogeneity & {$[13]$} \\
CD71 & Tumorigenicity & {$[14]$} \\
CD133 & Tumorigenicity, chemoresistance, tumor cell invasion & {$[15,16]$} \\
CXCR4 & Poor differentiation, independent prognostic factor & {$[17]$} \\
Lgr5 & Tumorigenicity, chemoresistance & {$[18,19]$} \\
\hline
\end{tabular}

\section{GCSCs and the Immune Microenvironment}

Cancer tissue consists of various stromal cells, such as fibroblasts, vascular endothelial cells, pericytes, bone marrow-derived cells and adipocytes [20]. Some evidence has shown that CSCs interact with their surroundings and stromal cells for adaptive advantage and survival [21].

For instance, stromal cells can support CSC development by undergoing various kinds of interactions and cell fusion to form hybrid tumor cells [22]. The microenvironment surrounding CSCs, called the "CSC niche", is known to regulate CSC properties, which regulate CSC proliferation and differentiation [23]. Recently, accumulating evidence has indicated that immune cells in the tumor microenvironment have an impact on cancer progression. In fact, the number of tumor-infiltrating macrophages affects cancer progression and prognosis, and these macrophages are called tumor-associated macrophages (TAMs) [24]. TAMs have been reported to contribute to tumor growth, cell extravasation and antitumor immunity in various types of cancer [25-28]. A few studies have demonstrated that TAMs provide pivotal signals to promote CSC survival, self-renewal, maintenance, and migration. In turn, CSCs deliver tumor-promoting cues to TAMs that further enhance tumorigenesis [29]. Milk-fat globule-epidermal growth factor-VIII (MFG-E8), which has been identified as a growth factor involving phagocytosis, angiogenesis, and immune tolerance, was highly produced from TAMs and could regulate the ability of CSCs to promote tumorigenicity and anticancer drug resistance [30]. Another study demonstrated that the interaction between TAMs and GCSCs was mediated by the expression of some factors, such as monocyte chemoattractant-1 (MCP-1), VEGF, cyclooxygenase-2 (COX-2)/PGE-2, and IFN- $\gamma$ [31]. We also investigated the interaction between TAMs and GCSC markers and delineated the molecular mechanism of CD44 induction that allowed infiltrated macrophages in the tumor microenvironment to contribute to redox adaptation through CD44 upregulation by miR-328 suppression [32].

Moreover, there is no doubt that cancer-associated fibroblasts (CAFs) have a critical role in maintaining the characteristics of TAMs, and the cell-cell interaction between CAFs and TAMs induces the recruitment and activation of each cell type [33,34]. CXCL12 derived from CAFs effectively attracts monocytes, and then the monocytes display the M2 macrophage phenotype, which supports tumor 
invasion and progression [35]. Based on this evidence, TAMs recruited by CAFs may promote GCSC properties through the upregulation of CSC marker expression. In addition, several compelling studies have shown that CAFs enhance CSC capabilities in GCSCs. CAFs significantly promote spheroid formation and the expression of CSC markers in GC cell lines, OCUM-12/side population (SP) cells and OCUM-2MD3/SP cells. The impacts of CAFs on GCSCs are remarkably blocked by TGF- $\beta$ inhibitors but not by fibroblast growth factor receptor or cMet inhibition. These findings suggest that CAFs may enhance GCSC properties through TGF- $\beta$ signaling [36]. Genome-wide DNA methylation and H3K27me3 analyses revealed that CAFs had diverse and distinct DNA methylation and H3K27me3 patterns. Moreover, the authors showed that loss of H3K27me3 in CAFs led to secretion of the cancer cell niche factors, and among these factors, WNT5A might promote the aggressive characteristics of GCSCs [37].

Immune checkpoint blockade is a current topic in cancer therapy. Because immune checkpoint pathways can maintain self-tolerance and limit collateral tissue damage during the antimicrobial immune response, cancer cells can evade immune damage by utilizing these pathways [38]. Nivolumab, a human monoclonal IgG4 antibody, can block the human programmed cell death-1 (PD-1) receptor. This antibody has been proven to be a treatment strategy for advanced cancer with significant clinical efficacy [39]. Based on clinical evidence, several studies have investigated the interaction between immune checkpoint-related molecules and CSCs.

For instance, programmed death-ligand 1 (PD-L1), which is highly expressed on the surface of CSCs, can inhibit T cell activity [40]. B7-H1 (also known as PD-L1)-positive GCSCs show a higher proliferative ability than B7-H1-negative GCSCs [41]. In contrast, CD4 positive T cells can differentiate into distinct subsets of T cells: suppressive regulatory $\mathrm{T}$ (Treg) cells and T helper 17 (Th17) cells. The functions of Th17 cells are contradictory due to the dual ability of these cells to promote or inhibit cancer [42]. A previous study showed that CSC s could affect the balance between Treg and Th17 subsets in several types of cancer by altering the cytokines in the tumor microenvironment [43]. However, Treg cells can promote the expansion of CSCs by secreting IL-17 in response to hypoxia [44]. Moreover, an investigation of Treg and Th17 cells revealed that STAT3 functioned as a critical transcription factor in Th17 differentiation and repressed the development of Treg cells [45]. In addition, STAT3 is highly expressed in GCSCs and has a role in stemness features and invasive properties [46,47]. Taken together, these findings suggest that STAT3 may be a key factor regulating GCSC properties and Th17/Treg cells. Although there is some evidence showing the effects of CSCs on Th17/Treg cells, the exact role of GCSCs in the balance between Treg and Th17 cells remains unclear.

Dendritic cells (DCs) are professional antigen-presenting cells (APCs) and the most effective activators of resting or naive T cells in vitro and in vivo [48]. A recent study using CD133 positive, CD29 positive and CD44 positive CSCs showed that the number of activated DCs was decreased after CSC lysate/LPS (intracellular) or CSC conditioned medium/LPS (extracellular) stimulation. This result suggested that CSCs might impair the functions of DCs [49]. Although the relationship between DCs and GCSCs is still unclear, the functional DCs are required in the immune microenvironment for T cell activation. Thus, the relationship should be determined by further investigations (Figure 1).

Based on the fact that cancer tissues consist of various types of cells in addition to cancer cells, we need to understand the network formed by these cells. A better understanding of the relationship between GCSCs and the immune microenvironment will lead to the development of novel therapeutic strategies for advanced GCs. 


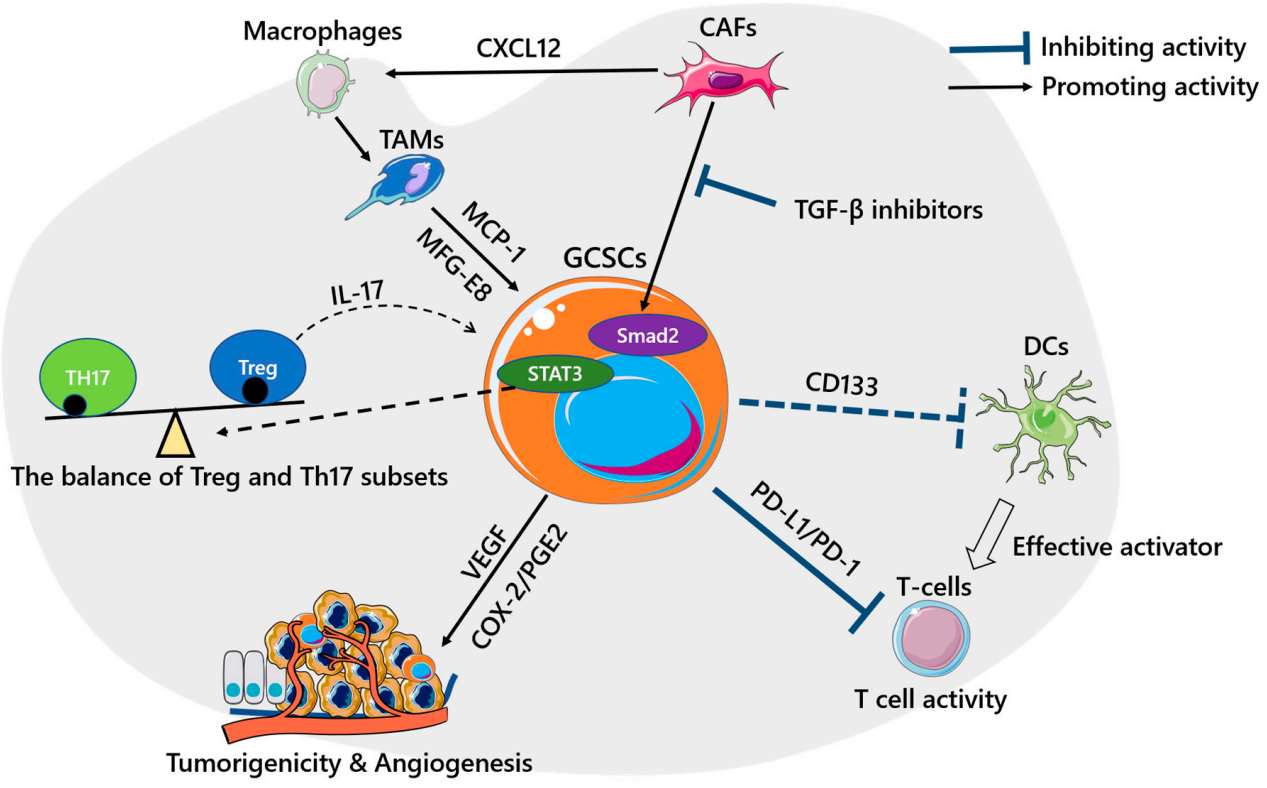

Figure 1. The roles of gastric cancer stem cells (GCSCs) in the immune microenvironment. Stromal cells can support GCSC development through various kinds of interactions. Tumor-associated macrophages (TAMs) enhance the induction of VEGF and COX2/PGE2 in GCSCs through monocyte chemoattractant-1 (MCP-1) and milk-fat globule-epidermal growth factor-VIII (MFG-E8). Cancer-associated fibroblasts (CAFs) not only directly enhance the CSC capabilities of GCSCs by activating the Smad2 pathway (TGF- $\beta$ inhibitors inhibit this process) but also attract macrophages that are converted into TAMs by CXCL12. GCSCs can inhibit T cell activity through the PD-L1/PD-1 interaction. Some theories suggest that GCSCs affect the balance of Treg and Th17 subsets, and GCSCs impair the function of dendritic cells (DCs). The solid line represents strong evidences supporting theory in GCSC; the dashed line represents possible evidences guide theory in GCSC.

\section{Current Target and Future Direction of GCSC Treatment}

Metastasis and recurrence are often detected in advanced GC patients after complete surgical resection, indicating that circulating tumor cells in the bloodstream or undetectable tumor nodules must exist at the time of surgery. Based on these experiences, there is a definitive consensus that compared with surgery alone, combination treatment strategies consisting of surgery with additional chemotherapy would improve the prognosis of GC patients [50]. However, conventional standard chemotherapy aimed at removing GC cells achieves limited benefits, which leads to a poor prognosis in advanced-stage GC patients. CSCs are thought to be enriched in the remaining cancer cell population after chemotherapy and at metastatic sites. Thus, targeting the vital molecules involved in the maintenance of CSCs enables the elimination of CSCs and improves the outcomes of cancer patients [51-53].

Therapies based on the CSC concept are emerging [52]. CD44, the most common CSC marker, could serve as a useful target for CSC immunotherapy [54,55]. Over the past several years, various monoclonal antibodies against CD44 or CD44v isoforms have been evaluated, such as $\mathrm{H} 90$ and p245 [56]. H90 reduces leukemic repopulation by targeting acute myelogenous leukemia stem cells [57]. P245 inhibits triple-negative basal-like breast tumor growth in xenograft mice [58]. Moreover, there are several clinical antitumor studies on anti-CD44 antibodies, such as bivatuzumab, which is a humanized monoclonal antibody against CD44v6 [59], and RO5429083, which targets glycosylated CD44 [60]. Because CD44 is highly and functionally expressed in GCSCs, antibody therapy against CD44 may be an effective anticancer tool as a CSC-targeting therapy [61]. In addition, anti-CD44v6 monoclonal antibody-conjugated cold nanostars were developed and can inhibit tumor growth and extend survival in orthotopic and subcutaneous xenograft tumor models of GC in nude mice [62]. 
In addition, CD133, which has a role as a CSC marker, is a possible therapeutic target in CD133-expressing cancer types [63]. Cytokine-induced killer (CIK) cells bound to an anti-CD3/anti-CD133 bispecific antibody (BsAb) (BsAb-CIKs) are an effector cell population targeting CSCs with high CD133 expression. BsAb-CIK cells have shown strong killing of pancreatic and hepatic cancer cells with high CD133 expression [64]. Recently, a phase I clinical trial investigated the effects of chimeric antigen receptor-modified T cells directed against CD133 (CART-133) on various cancers (hepatocellular carcinoma, pancreatic carcinomas, and colorectal carcinomas). Analysis of biopsied tissues by immunohistochemistry showed that CD133-positive cells were completely eliminated by CART-133 injection [65]. Several kinds of antibodies targeting CD133 have been developed in the past decade. Cytotoxic antibodies against CD133 effectively inhibit the proliferation of cultured GC cells [66]. Anti-CD44 and anti-CD133 antibody-conjugated all-trans retinoic acid-loaded poly (lactide-coglycolide)-lecithin-PEG nanoparticles (CD44/CD133-ATRA-PLPN) were developed to target both CD133-positive and CD44-positive GCSCs. CD44/CD133-ATRA-PLPN show higher inhibition of GCSC growth than single-targeted or nontargeted nanoparticles [67]. Based on the evidence regarding CD44 and CD133, other GCSC markers could be expected to function as therapeutic targets for the elimination of GCSCs.

In addition to CSC markers, CSC-related factors are also noteworthy. The Hippo pathway is a key signaling pathway that regulates organ size through the regulation of cell number and cell size [68]. Deregulation of the hippo pathway can induce tumors in model organisms and is often detected in various human carcinomas [69]. The transcriptional hippo pathway coactivator YAP1 upregulates sox9 expression to endow CSC properties to esophageal cancer cells [70]. Supporting these previous findings, verteporfin, which is a known YAP inhibitor, can inhibit the tumorigenic properties of GCSCs by targeting YAP1/TAZ-TEAD transcriptional activity [71]. In addition to targeting YAP1, verteporfin can downregulate the expression of heat shock protein 90 beta (HSP90) client proteins by blocking clusterin gene expression, resulting in cell death in GCSCs [72].

Hypermethylation of tumor suppressor genes plays a determinative role in carcinogenesis; thus, inhibitors of DNA methylation are taken seriously in molecular therapy [73]. Moreover, the inhibition of DNA methyltransferase (DNMT) can reduce the tumorigenicity of GCSCs [74]. Some potential CSC-related factors are known. For instance, the orphan receptor TR3 (also known as Nur77) can regulate cell proliferation and apoptosis [75,76]. TR3 is an essential factor in the maintenance of stem-like properties in GC cells [77]. Likewise, Sox 2 is involved in the determination of cell fate and regulation of embryonic development in cells and can enhance the tumorigenicity and chemoresistance of GCSCs [78]. Given their functional roles in GCSCs, TR3 and Sox2 may be possible therapeutic targets in GCSCs. In this section, we summarized the findings regarding GCSC-targeting therapies. Although evidence is accumulating, further clinical trials are required to prove the clinical significance of GCSC-targeting therapies.

\section{Conclusions and Future Perspectives}

Conventional chemotherapy and molecular targeted therapy in addition to surgical treatment play key roles in prolonging the survival of advanced-stage GC patients. However, clinical outcomes are still disappointing, and these combination therapies are not ideal as a treatment strategy for advanced GCs. The successful determination of CSC markers has allowed the detection of GCSCs, and abundant evidence has shown that GCSCs are often resistant to conventional chemotherapy and closely related to metastasis and recurrence. Moreover, the extensive evidence presented in this review suggests that the tumor microenvironment, especially the immune microenvironment, surrounding GCSCs plays an important role in maintaining the properties of GCSCs. These findings indicate that the CSC niche and niche factors may be potential targets to counteract CSC properties. Therefore, identifying unique molecules and their signaling interactions in the tumor microenvironment through further investigations may lead to the development of an approach complementary to conventional treatment, one that is directed against malignant cells themselves. 
Author Contributions: L.F., H.B. and T.I. conceived of the presented idea. L.F. developed the theory and wrote the manuscript with support from L.B. and T.I., T.Y., M.K., T.A. and T.U. provided critical feedback, all authors helped shape the manuscript. All authors have read and agreed to the published version of the manuscript.

Funding: This work was supported by Japan Society for the Promotion of Science (JSPS) KAKENHI grant no. 16H06257 and 18K08543, 19K16720, by the Princess Takamatsu Cancer Research Fund.

Conflicts of Interest: The authors declare that they have no conflict of interest.

\section{References}

1. Torre, L.A.; Bray, F.; Siegel, R.L.; Ferlay, J.; Lortet-Tieulent, J.; Jemal, A. Global cancer statistics, 2012. CA Cancer J. Clin. 2015, 65, 87-108. [CrossRef]

2. Parkin, D.M. The global health burden of infection-associated cancers in the year 2002. Int. J. Cancer 2006, 118, 3030-3044. [CrossRef]

3. Vermeulen, L.; de Sousa e Melo, F.; Richel, D.J.; Medema, J.P. The developing cancer stem-cell model: Clinical challenges and opportunities. Lancet Oncol. 2012, 13, e83-e89. [CrossRef]

4. Brungs, D.; Aghmesheh, M.; Vine, K.L.; Becker, T.M.; Carolan, M.G.; Ranson, M. Gastric cancer stem cells: Evidence, potential markers, and clinical implications. J. Gastroenterol. 2016, 51, 313-326. [CrossRef] [PubMed]

5. Ishimoto, T.; Sawayama, H.; Sugihara, H.; Baba, H. Interaction between gastric cancer stem cells and the tumor microenvironment. J. Gastroenterol. 2014, 49, 1111-1120. [CrossRef]

6. Takaishi, S.; Okumura, T.; Tu, S.; Wang, S.S.; Shibata, W.; Vigneshwaran, R.; Gordon, S.A.; Shimada, Y.; Wang, T.C. Identification of gastric cancer stem cells using the cell surface marker CD44. Stem Cells 2009, 27, 1006-1020. [CrossRef] [PubMed]

7. Zhang, C.; Li, C.; He, F.; Cai, Y.; Yang, H. Identification of CD44+CD24+ gastric cancer stem cells. J. Cancer Res. Clin. Oncol. 2011, 137, 1679-1686. [CrossRef]

8. Chen, T.; Yang, K.; Yu, J.; Meng, W.; Yuan, D.; Bi, F.; Liu, F.; Liu, J.; Dai, B.; Chen, X.; et al. Identification and expansion of cancer stem cells in tumor tissues and peripheral blood derived from gastric adenocarcinoma patients. Cell Res. 2012, 22, 248-258. [CrossRef]

9. Han, M.E.; Jeon, T.Y.; Hwang, S.H.; Lee, Y.S.; Kim, H.J.; Shim, H.E.; Yoon, S.; Baek, S.Y.; Kim, B.S.; Kang, C.D.; et al. Cancer spheres from gastric cancer patients provide an ideal model system for cancer stem cell research. Cell. Mol. Life Sci. 2011, 68, 3589-3605. [CrossRef] [PubMed]

10. Katsuno, Y.; Ehata, S.; Yashiro, M.; Yanagihara, K.; Hirakawa, K.; Miyazono, K. Coordinated expression of REG4 and aldehyde dehydrogenase 1 regulating tumourigenic capacity of diffuse-type gastric carcinoma-initiating cells is inhibited by TGF-beta. J. Pathol. 2012, 228, 391-404. [CrossRef] [PubMed]

11. Nguyen, P.H.; Giraud, J.; Chambonnier, L.; Dubus, P.; Wittkop, L.; Belleannee, G.; Collet, D.; Soubeyran, I.; Evrard, S.; Rousseau, B.; et al. Characterization of Biomarkers of Tumorigenic and Chemoresistant Cancer Stem Cells in Human Gastric Carcinoma. Clin. Cancer Res. 2017, 23, 1586-1597. [CrossRef]

12. Liu, J.; Ma, L.; Xu, J.; Liu, C.; Zhang, J.; Liu, J.; Chen, R.; Zhou, Y. Spheroid body-forming cells in the human gastric cancer cell line MKN-45 possess cancer stem cell properties. Int. J. Oncol. 2013, 42, 453-459. [CrossRef] [PubMed]

13. Jiang, J.; Zhang, Y.; Chuai, S.; Wang, Z.; Zheng, D.; Xu, F.; Zhang, Y.; Li, C.; Liang, Y.; Chen, Z. Trastuzumab (herceptin) targets gastric cancer stem cells characterized by CD90 phenotype. Oncogene 2012, 31, 671-682. [CrossRef] [PubMed]

14. Ohkuma, M.; Haraguchi, N.; Ishii, H.; Mimori, K.; Tanaka, F.; Kim, H.M.; Shimomura, M.; Hirose, H.; Yanaga, K.; Mori, M. Absence of CD71 transferrin receptor characterizes human gastric adenosquamous carcinoma stem cells. Ann. Surg. Oncol. 2012, 19, 1357-1364. [CrossRef] [PubMed]

15. Jiang, Y.; He, Y.; Li, H.; Li, H.N.; Zhang, L.; Hu, W.; Sun, Y.M.; Chen, F.L.; Jin, X.M. Expressions of putative cancer stem cell markers ABCB1, ABCG2, and CD133 are correlated with the degree of differentiation of gastric cancer. Gastric Cancer 2012, 15, 440-450. [CrossRef]

16. Hashimoto, K.; Aoyagi, K.; Isobe, T.; Kouhuji, K.; Shirouzu, K. Expression of CD133 in the cytoplasm is associated with cancer progression and poor prognosis in gastric cancer. Gastric Cancer 2014, 17, 97-106. [CrossRef] 
17. Fujita, T.; Chiwaki, F.; Takahashi, R.U.; Aoyagi, K.; Yanagihara, K.; Nishimura, T.; Tamaoki, M.; Komatsu, M.; Komatsuzaki, R.; Matsusaki, K.; et al. Identification and Characterization of CXCR4-Positive Gastric Cancer Stem Cells. PLoS ONE 2015, 10, e0130808. [CrossRef]

18. de Sousa e Melo, F.; Kurtova, A.V.; Harnoss, J.M.; Kljavin, N.; Hoeck, J.D.; Hung, J.; Anderson, J.E.; Storm, E.E.; Modrusan, Z.; Koeppen, H.; et al. A distinct role for Lgr5(+) stem cells in primary and metastatic colon cancer. Nature 2017, 543, 676-680. [CrossRef]

19. Gong, X.; Azhdarinia, A.; Ghosh, S.C.; Xiong, W.; An, Z.; Liu, Q.; Carmon, K.S. LGR5-Targeted Antibody-Drug Conjugate Eradicates Gastrointestinal Tumors and Prevents Recurrence. Mol. Cancer Ther. 2016, 15, 1580-1590. [CrossRef]

20. Bussard, K.M.; Mutkus, L.; Stumpf, K.; Gomez-Manzano, C.; Marini, F.C. Tumor-associated stromal cells as key contributors to the tumor microenvironment. Breast Cancer Res. 2016, 18, 84. [CrossRef]

21. Brown, Y.; Hua, S.; Tanwar, P.S. Extracellular matrix-mediated regulation of cancer stem cells and chemoresistance. Int. J. Biochem. Cell Biol. 2019, 109, 90-104. [CrossRef] [PubMed]

22. Melzer, C.; von der Ohe, J.; Lehnert, H.; Ungefroren, H.; Hass, R. Cancer stem cell niche models and contribution by mesenchymal stroma/stem cells. Mol. Cancer 2017, 16, 28. [CrossRef] [PubMed]

23. Baba, H.; Ishimoto, T. Targeting cancer stem cells in gastric cancer. Gastrointest. Cancer Targets Ther. 2014. [CrossRef]

24. Ghesquiere, B.; Wong, B.W.; Kuchnio, A.; Carmeliet, P. Metabolism of stromal and immune cells in health and disease. Nature 2014, 511, 167-176. [CrossRef] [PubMed]

25. Komohara, Y.; Ohnishi, K.; Kuratsu, J.; Takeya, M. Possible involvement of the M2 anti-inflammatory macrophage phenotype in growth of human gliomas. J. Pathol. 2008, 216, 15-24. [CrossRef] [PubMed]

26. Hasita, H.; Komohara, Y.; Okabe, H.; Masuda, T.; Ohnishi, K.; Lei, X.F.; Beppu, T.; Baba, H.; Takeya, M. Significance of alternatively activated macrophages in patients with intrahepatic cholangiocarcinoma. Cancer Sci. 2010, 101, 1913-1919. [CrossRef]

27. Sica, A.; Mantovani, A. Macrophage plasticity and polarization: In vivo veritas. J. Clin. Investig. 2012, 122, 787-795. [CrossRef]

28. De Palma, M.; Lewis, C.E. Macrophage regulation of tumor responses to anticancer therapies. Cancer Cell 2013, 23, 277-286. [CrossRef]

29. Sainz, B., Jr.; Carron, E.; Vallespinos, M.; Machado, H.L. Cancer Stem Cells and Macrophages: Implications in Tumor Biology and Therapeutic Strategies. Mediat. Inflamm. 2016, 2016, 9012369. [CrossRef]

30. Jinushi, M.; Chiba, S.; Yoshiyama, H.; Masutomi, K.; Kinoshita, I.; Dosaka-Akita, H.; Yagita, H.; Takaoka, A.; Tahara, H. Tumor-associated macrophages regulate tumorigenicity and anticancer drug responses of cancer stem/initiating cells. Proc. Natl. Acad. Sci. USA 2011, 108, 12425-12430. [CrossRef]

31. Zhang, C.; Hu, X.; Liu, X.Y.; Liang, P.; Zhang, J.; Cao, L.; Wang, Z.L.; Liu, H.R.; Yin, X.G.; Dong, C.Y.; et al. Effect of tumor-associated macrophages on gastric cancer stem cell in omental milky spots and lymph node micrometastasis. Int. J. Clin. Exp. Pathol. 2015, 8, 13795-13805. [PubMed]

32. Ishimoto, T.; Sugihara, H.; Watanabe, M.; Sawayama, H.; Iwatsuki, M.; Baba, Y.; Okabe, H.; Hidaka, K.; Yokoyama, N.; Miyake, K.; et al. Macrophage-derived reactive oxygen species suppress miR-328 targeting CD44 in cancer cells and promote redox adaptation. Carcinogenesis 2014, 35, 1003-1011. [CrossRef] [PubMed]

33. Hashimoto, O.; Yoshida, M.; Koma, Y.; Yanai, T.; Hasegawa, D.; Kosaka, Y.; Nishimura, N.; Yokozaki, H. Collaboration of cancer-associated fibroblasts and tumour-associated macrophages for neuroblastoma development. J. Pathol. 2016, 240, 211-223. [CrossRef] [PubMed]

34. Komohara, Y.; Takeya, M. CAFs and TAMs: Maestros of the tumour microenvironment. J. Pathol. 2017, 241, 313-315. [CrossRef] [PubMed]

35. Li, X.; Bu, W.; Meng, L.; Liu, X.; Wang, S.; Jiang, L.; Ren, M.; Fan, Y.; Sun, H. CXCL12/CXCR4 pathway orchestrates CSC-like properties by CAF recruited tumor associated macrophage in OSCC. Exp. Cell Res. 2019, 378, 131-138. [CrossRef]

36. Hasegawa, T.; Yashiro, M.; Nishii, T.; Matsuoka, J.; Fuyuhiro, Y.; Morisaki, T.; Fukuoka, T.; Shimizu, K.; Shimizu, T.; Miwa, A.; et al. Cancer-associated fibroblasts might sustain the stemness of scirrhous gastric cancer cells via transforming growth factor-beta signaling. Int. J. Cancer 2014, 134, 1785-1795. [CrossRef]

37. Maeda, M.; Takeshima, H.; Iida, N.; Hattori, N.; Yamashita, S.; Moro, H.; Yasukawa, Y.; Nishiyama, K.; Hashimoto, T.; Sekine, S.; et al. Cancer cell niche factors secreted from cancer-associated fibroblast by loss of H3K27me3. Gut 2019. [CrossRef] 
38. Topalian, S.L.; Drake, C.G.; Pardoll, D.M. Immune checkpoint blockade: A common denominator approach to cancer therapy. Cancer Cell 2015, 27, 450-461. [CrossRef]

39. Ishimoto, T.; Nagano, O.; Yae, T.; Tamada, M.; Motohara, T.; Oshima, H.; Oshima, M.; Ikeda, T.; Asaba, R.; Yagi, H.; et al. CD44 variant regulates redox status in cancer cells by stabilizing the $\mathrm{xCT}$ subunit of system xc(-) and thereby promotes tumor growth. Cancer Cell 2011, 19, 387-400. [CrossRef]

40. Sultan, M.; Coyle, K.M.; Vidovic, D.; Thomas, M.L.; Gujar, S.; Marcato, P. Hide-and-seek: The interplay between cancer stem cells and the immune system. Carcinogenesis 2017, 38, 107-118. [CrossRef]

41. Yang, Y.; Wu, K.E.; Zhao, E.; Li, W.; Shi, L.; Xie, G.; Jiang, B.; Wang, Y.; Li, R.; Zhang, P.; et al. B7-H1 enhances proliferation ability of gastric cancer stem-like cells as a receptor. Oncol. Lett. 2015, 9, 1833-1838. [CrossRef]

42. Knochelmann, H.M.; Dwyer, C.J.; Bailey, S.R.; Amaya, S.M.; Elston, D.M.; Mazza-McCrann, J.M.; Paulos, C.M. When worlds collide: Th17 and Treg cells in cancer and autoimmunity. Cell. Mol. Immunol. 2018, 15, 458-469. [CrossRef] [PubMed]

43. Rezalotfi, A.; Ahmadian, E.; Aazami, H.; Solgi, G.; Ebrahimi, M. Gastric Cancer Stem Cells Effect on Th17/Treg Balance; A Bench to Beside Perspective. Front. Oncol. 2019, 9, 226. [CrossRef] [PubMed]

44. Yang, S.; Wang, B.; Guan, C.; Wu, B.; Cai, C.; Wang, M.; Zhang, B.; Liu, T.; Yang, P. Foxp3+IL-17+ T cells promote development of cancer-initiating cells in colorectal cancer. J. Leukoc. Biol. 2011, 89, 85-91. [CrossRef] [PubMed]

45. Chaudhry, A.; Rudra, D.; Treuting, P.; Samstein, R.M.; Liang, Y.; Kas, A.; Rudensky, A.Y. CD4+ regulatory T cells control TH17 responses in a Stat3-dependent manner. Science 2009, 326, 986-991. [CrossRef] [PubMed]

46. Avalle, L.; Camporeale, A.; Camperi, A.; Poli, V. STAT3 in cancer: A double edged sword. Cytokine 2017, 98, 42-50. [CrossRef] [PubMed]

47. Hajimoradi, M.; Mohammad Hassan, Z.; Ebrahimi, M.; Soleimani, M.; Bakhshi, M.; Firouzi, J.; Samani, F.S. STAT3 is Overactivated in Gastric Cancer Stem-Like Cells. Cell J. 2016, 17, 617-628. [CrossRef] [PubMed]

48. Adams, S.; O’Neill, D.W.; Bhardwaj, N. Recent advances in dendritic cell biology. J. Clin. Immunol. 2005, 25, 87-98. [CrossRef]

49. Szarynska, M.; Olejniczak, A.; Kobiela, J.; Laski, D.; Sledzinski, Z.; Kmiec, Z. Cancer stem cells as targets for DC-based immunotherapy of colorectal cancer. Sci. Rep. 2018, 8, 12042. [CrossRef]

50. Charalampakis, N.; Economopoulou, P.; Kotsantis, I.; Tolia, M.; Schizas, D.; Liakakos, T.; Elimova, E.; Ajani, J.A.; Psyrri, A. Medical management of gastric cancer: A 2017 update. Cancer Med. 2018, 7, 123-133. [CrossRef]

51. Wang, J.C. Evaluating therapeutic efficacy against cancer stem cells: New challenges posed by a new paradigm. Cell Stem Cell 2007, 1, 497-501. [CrossRef] [PubMed]

52. Batlle, E.; Clevers, H. Cancer stem cells revisited. Nat. Med. 2017, 23, 1124-1134. [CrossRef] [PubMed]

53. Guo, W.; Lasky, J.L., 3rd; Wu, H. Cancer stem cells. Pediatric Res. 2006, 59, 59R-64R. [CrossRef] [PubMed]

54. Naor, D.; Sionov, R.V.; Ish-Shalom, D. CD44: Structure, function, and association with the malignant process. Adv. Cancer Res. 1997, 71, 241-319. [CrossRef]

55. Pan, Q.; Li, Q.; Liu, S.; Ning, N.; Zhang, X.; Xu, Y.; Chang, A.E.; Wicha, M.S. Concise Review: Targeting Cancer Stem Cells Using Immunologic Approaches. Stem Cells 2015, 33, 2085-2092. [CrossRef]

56. Yan, Y.; Zuo, X.; Wei, D. Concise Review: Emerging Role of CD44 in Cancer Stem Cells: A Promising Biomarker and Therapeutic Target. Stem Cells Transl. Med. 2015, 4, 1033-1043. [CrossRef]

57. Jin, L.; Hope, K.J.; Zhai, Q.; Smadja-Joffe, F.; Dick, J.E. Targeting of CD44 eradicates human acute myeloid leukemic stem cells. Nat. Med. 2006, 12, 1167-1174. [CrossRef]

58. Marangoni, E.; Lecomte, N.; Durand, L.; de Pinieux, G.; Decaudin, D.; Chomienne, C.; Smadja-Joffe, F.; Poupon, M.F. CD44 targeting reduces tumour growth and prevents post-chemotherapy relapse of human breast cancers xenografts. Br. J. Cancer 2009, 100, 918-922. [CrossRef]

59. Tijink, B.M.; Buter, J.; de Bree, R.; Giaccone, G.; Lang, M.S.; Staab, A.; Leemans, C.R.; van Dongen, G.A. A phase I dose escalation study with anti-CD44v6 bivatuzumab mertansine in patients with incurable squamous cell carcinoma of the head and neck or esophagus. Clin. Cancer Res. 2006, 12, 6064-6072. [CrossRef]

60. Rupp, U.; Schoendorf-Holland, E.; Eichbaum, M.; Schuetz, F.; Lauschner, I.; Schmidt, P.; Staab, A.; Hanft, G.; Huober, J.; Sinn, H.P.; et al. Safety and pharmacokinetics of bivatuzumab mertansine in patients with CD44v6-positive metastatic breast cancer: Final results of a phase I study. Anti-Cancer Drugs 2007, 18, 477-485. [CrossRef] 
61. Jang, B.I.; Li, Y.; Graham, D.Y.; Cen, P. The Role of CD44 in the Pathogenesis, Diagnosis, and Therapy of Gastric Cancer. Gut Liver 2011, 5, 397-405. [CrossRef] [PubMed]

62. Liang, S.; Li, C.; Zhang, C.; Chen, Y.; Xu, L.; Bao, C.; Wang, X.; Liu, G.; Zhang, F.; Cui, D. CD44v6 Monoclonal Antibody-Conjugated Gold Nanostars for Targeted Photoacoustic Imaging and Plasmonic Photothermal Therapy of Gastric Cancer Stem-like Cells. Theranostics 2015, 5, 970-984. [CrossRef] [PubMed]

63. Rappa, G.; Fodstad, O.; Lorico, A. The stem cell-associated antigen CD133 (Prominin-1) is a molecular therapeutic target for metastatic melanoma. Stem Cells 2008, 26, 3008-3017. [CrossRef] [PubMed]

64. Huang, J.; Li, C.; Wang, Y.; Lv, H.; Guo, Y.; Dai, H.; Wicha, M.S.; Chang, A.E.; Li, Q. Cytokine-induced killer (CIK) cells bound with anti-CD3/anti-CD133 bispecific antibodies target CD133(high) cancer stem cells in vitro and in vivo. Clin. Immunol. 2013, 149, 156-168. [CrossRef]

65. Wang, Y.; Chen, M.; Wu, Z.; Tong, C.; Dai, H.; Guo, Y.; Liu, Y.; Huang, J.; Lv, H.; Luo, C.; et al. CD133-directed CAR T cells for advanced metastasis malignancies: A phase I trial. Oncoimmunology 2018, 7, e1440169. [CrossRef]

66. Smith, L.M.; Nesterova, A.; Ryan, M.C.; Duniho, S.; Jonas, M.; Anderson, M.; Zabinski, R.F.; Sutherland, M.K.; Gerber, H.P.; Van Orden, K.L.; et al. CD133/prominin-1 is a potential therapeutic target for antibody-drug conjugates in hepatocellular and gastric cancers. Br. J. Cancer 2008, 99, 100-109. [CrossRef]

67. Chen, H.; Lin, J.; Shan, Y.; Zhengmao, L. The promotion of nanoparticle delivery to two populations of gastric cancer stem cells by CD133 and CD44 antibodies. Biomed. Pharmacother. Biomed. Pharmacother. 2019, 115, 108857. [CrossRef]

68. Tumaneng, K.; Russell, R.C.; Guan, K.L. Organ size control by Hippo and TOR pathways. Curr. Biol. 2012, 22, R368-R379. [CrossRef]

69. Harvey, K.F.; Zhang, X.; Thomas, D.M. The Hippo pathway and human cancer. Nat. Rev. Cancer 2013, 13, 246-257. [CrossRef]

70. Song, S.; Ajani, J.A.; Honjo, S.; Maru, D.M.; Chen, Q.; Scott, A.W.; Heallen, T.R.; Xiao, L.; Hofstetter, W.L.; Weston, B.; et al. Hippo coactivator YAP1 upregulates SOX9 and endows esophageal cancer cells with stem-like properties. Cancer Res. 2014, 74, 4170-4182. [CrossRef]

71. Giraud, J.; Molina-Castro, S.; Seeneevassen, L.; Sifre, E.; Izotte, J.; Tiffon, C.; Staedel, C.; Boeuf, H.; Fernandez, S.; Barthelemy, P.; et al. Verteporfin targeting YAP1/TAZ-TEAD transcriptional activity inhibits the tumorigenic properties of gastric cancer stem cells. Int. J. Cancer 2019. [CrossRef] [PubMed]

72. Xiong, J.; Wang, S.; Chen, T.; Shu, X.; Mo, X.; Chang, G.; Chen, J.J.; Li, C.; Luo, H.; Lee, J.D. Verteporfin blocks Clusterin which is required for survival of gastric cancer stem cell by modulating HSP90 function. Int. J. Biol. Sci. 2019, 15, 312-324. [CrossRef] [PubMed]

73. McCabe, M.T.; Brandes, J.C.; Vertino, P.M. Cancer DNA methylation: Molecular mechanisms and clinical implications. Clin. Cancer Res. 2009, 15, 3927-3937. [CrossRef] [PubMed]

74. Norollahi, S.E.; Mansour-Ghanaei, F.; Joukar, F.; Ghadarjani, S.; Mojtahedi, K.; Gharaei Nejad, K.; Hemmati, H.; Gharibpoor, F.; Khaksar, R.; Samadani, A.A. Therapeutic approach of Cancer stem cells (CSCs) in gastric adenocarcinoma; DNA methyltransferases enzymes in cancer targeted therapy. Biomed. Pharmacother. Biomed. Pharmacother. 2019, 115, 108958. [CrossRef] [PubMed]

75. Li, H.; Kolluri, S.K.; Gu, J.; Dawson, M.I.; Cao, X.; Hobbs, P.D.; Lin, B.; Chen, G.; Lu, J.; Lin, F.; et al. Cytochrome $\mathrm{c}$ release and apoptosis induced by mitochondrial targeting of nuclear orphan receptor TR3. Science 2000, 289, 1159-1164. [CrossRef] [PubMed]

76. Pei, L.; Waki, H.; Vaitheesvaran, B.; Wilpitz, D.C.; Kurland, I.J.; Tontonoz, P. NR4A orphan nuclear receptors are transcriptional regulators of hepatic glucose metabolism. Nat. Med. 2006, 12, 1048-1055. [CrossRef] [PubMed]

77. Zhan, Y.Y.; He, J.P.; Chen, H.Z.; Wang, W.J.; Cai, J.C. Orphan receptor TR3 is essential for the maintenance of stem-like properties in gastric cancer cells. Cancer Lett. 2013, 329, 37-44. [CrossRef]

78. Tian, T.; Zhang, Y.; Wang, S.; Zhou, J.; Xu, S. Sox2 enhances the tumorigenicity and chemoresistance of cancer stem-like cells derived from gastric cancer. J. Biomed. Res. 2012, 26, 336-345. [CrossRef]

(C) 2020 by the authors. Licensee MDPI, Basel, Switzerland. This article is an open access article distributed under the terms and conditions of the Creative Commons Attribution (CC BY) license (http://creativecommons.org/licenses/by/4.0/). 